\title{
LABOR POLICY AND DEFENSE CONTRACTS: A MATTER OF MISSION
}

\author{
STEPHEN N. SHULMAN
}

\section{INTRODUCTION}

Any study of labor policy and defense contracts must start with one fundamental fact: the mission of the Department of Defense-the agency that lets the contracts and thus wields whatever economic power the government as customer may possessis neither labor policy nor contracting. The student of labor policy and defense contracts must begin his analysis, and draw his conclusions, with a full appreciation of this foundation. The mission of the Department of Defense underlies and explains the procedures and practices that are followed. Conclusive and ubiquitous is its influence.

As with all departments and agencies, the Department of Defense of course adheres to the fundamental policies of the government. Established policy applies alike throughout.

The basic labor policy of our government, of our country, is freedom. We are dedicated to a free enterprise system. Equally are we dedicated to free labor. For relations between labor and management, free collective bargaining is the watchword. The Wagner Act, as amended by the Taft-Hartley and Landrum-Griffin Acts, ${ }^{1}$ has firmly rooted free collective bargaining in our national life.

Free labor and free management have worked with the Department of Defense to make our nation strong and secure. Their accomplishments have been enormous. If our modern weapons systems appear the conception of science fiction writers, let us not forget that these remarkable scientific achievements have been produced by free labor and free management. Production of one modern missile may involve the manufacture and assembly of a quarter million parts. Construction of a missile site may mean the handling of thousands of tons of materials. Add to these quantitative indices the closest of tolerances and the tightest of specifications, all within a pressing time demand, and the beginnings of appreciating the contribution of free labor and management to our defense posture emerge.

Formulation of labor policy is distinctly a civilian concern. Ours is a nation of civilian, not military control. That labor policy is beyond the stated jurisdiction of the Department of Defense is understandable on this score alone.

Labor policy also lies beyond the assigned concern of the other government agencies, which are civilian, that engage in the contracting process. For them too,

*A.B. 1954, Harvard University; LL.B. 1958, Yale University. Member of Connecticut, District of Columbia, and United States Supreme Court bars. Deputy Assistant Secretary of Defense (Civilian Personnel and Industrial Relations) since 1962; formerly Executive Assistant to the Secretary of Labor.

${ }^{1} 6$ I Stat. 136 (I947), 29 U.S.C. $\$ \$$ I5I-I68 (1958), 73 Stat. 519 (I959), 29 U.S.C. $\$ 5$ 40I-531 (Supp. IV, 1963$)$. 
contracting-procurement-is not the mission but simply a means by which it is fulfilled. ${ }^{2}$

As a result, a review of labor policy and defense contracts will largely serve the same purposes as one including all government contracts. Defense contracts, moreover, constitute a particularly good model. They cover a wide range of goods and services, from shoes to missiles, from building maintenance to elaborate research. ${ }^{3}$ They constitute the major part of all government procurement. And they have formed the basis of most of the history that facilitates understanding of labor policy and government contracts.

The mission of the Department of Defense is the defense of the nation. ${ }^{4}$ No more, no less. Contracting is one means by which that mission is fulfilled. It is not the sole means; neither, of course, is it an unimportant or insignificant one. Labor policy is one aspect of contracting. It, again, is neither the sole nor an unimportant or insignificant aspect.

Labor policy is the mission of other government agencies. The Department of Labor is, plainly, the paramount arm of government for labor policy. ${ }^{5}$ The Secretary of Labor is the chief adviser to the President on labor matters. Within that overall framework, other agencies perform specific missions of labor policy. The National Labor Relations Board patrols the relationships between labor and management, employees and unions, in interpreting and enforcing the Taft-Hartley Act. When the labor-management relationship strains, when disputes develop, the Federal Mediation and Conciliation Service stands ready with mediatory assistance to parties whose relations are governed by Taft-Hartley. ${ }^{6}$ The National Mediation Board is similarly available to parties subject to the Railway Labor Act. ${ }^{7}$

\footnotetext{
3 Two agencies of government other than the Defense Department procure more than $\$ x$ billion annually. One, the National Aeronautics and Space Administration (NASA), was organized to provide the expansion of human knowledge, improvement of aeronautical and space vehicles, long range studies, and the like. 42 U.S.C. $\$ 245 I$ (c) (1958). The other, the Atomic Energy Commission (AEC), was established to provide for the promotion of research and development; control of information; control of the possession, use and production of atomic energy and special nuclear material; international cooperation, and so forth, all to the end of stimulating scientific and industrial progress and furthering national defense, security, and welfare. 68 Stat. 922 (1954), 42 U.S.C. $\$ 20{ }_{3}$ (1958). The General Services Administration does function as the general purchasing agent for the government and, as such, might be considered to have procurement as its mission. However, the General Services Administration also furnishes services to other government agencies with its own work force and without contract. In addition, the Administrator is required to act "in respect of executive agencies... and with due regard to the program activities of the agencies concerned," 64 Stat. 578 (1949), 5 U.S.C. $\$ 630$ (1958), thus effectively acquiring their missions.

${ }^{3}$ E.g., 8,868,549 separate procurement actions were effected within the Department Department during Fiscal Year ig63. Office of the Secretary of Defense, Mrlitary Prime Contracts awards and Subcontracts Payments (1963).

¿ See 55 Stat. 628 (I94I), 50 U.S.C. $\$ 401$ (1958).

37 Stat. 736 (x913), 5 U.S.C. $\$ 6 \mathrm{Ix}$ (1958).

${ }^{\circ} 6$ I Stat. $152-56$ (1947), 29 U.S.C. $\$ \S 17 x-182$ (1958).

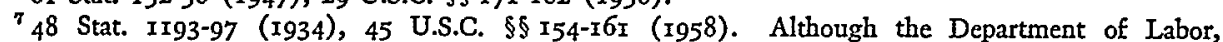
National Labor Relations Board, Federal Mediation and Conciliation Service, and the National Mediation Board are generally the most prominent of the agencies concerned with labor matters, they by no means comprise the entire list. In the railroad field, the National Railroad Adjustment Board resolves grievances
} 
The contracting function thrusts the Department of Defense into the arena of labor policy. Historically and today, this process takes place inexorably, despite intention. When the Department of Defense becomes a customer, it needs must encounter the implications of labor policy that face any buyer. The problems raised by this simple operation of market place realities are heightened by the fact that the Department of Defense as a customer is the same entity as the Department of Defense as a Cabinet arm of government. ${ }^{8}$ Its options in the market place are dictated by the fundamental devotion to fairness and impartiality that is properly required of all government activities. Its options are delimited, moreover, by the host of laws, regulations, and directives that expectably surround the administration of a governmental agency and that are particularly demanded of a military institution whose civilian employees alone approximate one million. ${ }^{10}$

Although the Department's contracts involve great financial amounts, its overall economic influence is easily exaggerated. Defense procurement currently accounts for some $\$ 30$ billion annually. Certainly, annual expenditures of that magnitude assert an economic influence. The limits of that influence, however, should be clearly understood. The impacts of defense procurement upon regional and state economies, for example, constitute but one-and only one-factor in the determination of general prosperity patterns. Defense procurement is not, accordingly, the measure of any given unemployment problem. Thus, the state of Kansas suffered a 66.3 per cent loss in prime contract awards between fiscal year 1958 and fiscal year I962. But the unemployment rate in Kansas in calendar year 1962 was relatively low. Conversely, California experienced a 34.4 per cent increase in prime contract awards during the same period; yet its unemployment rate in 1962 was not low. Had the I958 rate of prime contract awards remained the same in these two states in 1962 , Kansas might well have had less unemployment and California more, of course. Still, the decrease in awards to the one and the increase to the other were-to say the least-incomplete descriptions of the economic well-being of each. ${ }^{11}$

On the other hand, the economic influence of defense procurement in a particular plant-or even industry-can be great indeed. Problems of conversion to non-military goods or uses aside, any given plant, or certainly line within a plant, may well be

under collective bargaining agreements, 48 Stat. II89 (I934), 45 U.S.C. $\$$ I53 (I958), and the Railroad Retirement Board administers the Railroad Retirement Act, 63 Stat. I07 (r949), 45 U.S.C. $\$ 228$ j (1958), and the Railroad Unemployment Insurance Act, 63 Stat. 107 (1949), 45 U.S.C. $\$ 355$ (1958). Also with respect to government employees, the Civil Service Commission is charged with execution, administration, and enforcement of a myriad of laws, orders and regulations. 52 Stat. II94 (1938), 5 U.S.C. $\$ 62$ (1958). In addition, a number of agencies established for other purposes have incidental labor responsibilities. E.g., the Interstate Commerce Commission is charged with enforcement of the statutory work day and hours limits for the railroad industry. 34 Stat. 1417 (1907), as amended, 45 U.S.C. $\$ 64$ (1958).

${ }^{8}$ The traditional distinction between proprietary and sovereign attributes of government is not relevant to this point.

${ }^{9}$ E.g., Department of Defense Directive 5500.7, Standards of Conduct, May 17, 1963.

${ }^{10}$ President Johnson has called for the lowest civilian employment level in the Department of Defense since 1950 , which will reduce the number below one million. State of the Union Message, Jan. 8, 1964 , I Io Cong. REc. Ior (daily ed. Jan. 8, 1964).

${ }^{11}$ The following chart highlights this point: 
taken up entirely with defense production. A construction project may easily be devoted totally to a defense purpose. Many important companies with substantial payrolls are overwhelmingly engaged in defense work. ${ }^{12}$ In these cases, employees naturally see their employment as dependent on defense procurement. They look to the Department of Defense as much as to their employer for job security. ${ }^{13}$ By the same token, managements view their profit structures as intimately bound up with defense contracts.

This hard reality defines the height of Defense Department involvement in labor policy. Collective bargaining in such cases is conducted under an umbrella of concern for the viability of a current defense contract or the likelihood of successful competition for a new one. Management must make its responses to labor's demands

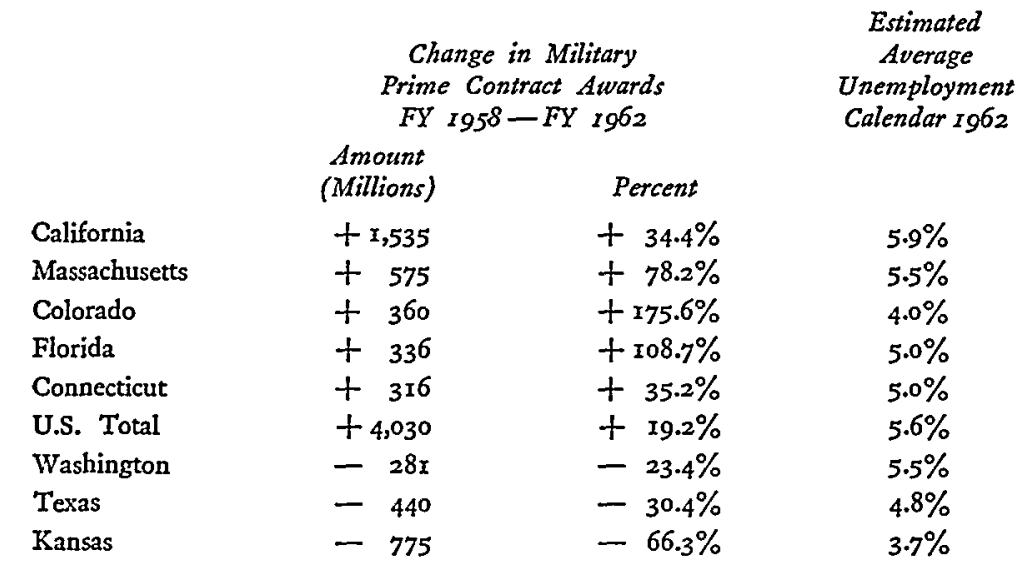

Source: Office of the Secretary of Defense, Five Year Trends in Defense Procurement, 1958-1962 $(\mathrm{r} 963)$.

${ }^{13}$ For example, Lockheed Aircraft Corporation, General Dynamics Corporation, and Bocing Company, the three largest defense contractors in terms of dollar value of awarded contracts during fiscal year 1962 , received in that year contracts totaling $\$ 1,383,900,000, \$ 1,196,600,000$ and $\$ 1,132,800,000$ respectively. This compared with respective net sales of $\$ 1,753,074,000, \$ 1,898,481,708$ and $\$ 1,768,535,000$ during Calendar Year 1962. That such intensive involvement in defense contracting is not restricted to large contractors is indicated by the figures for Vitro Corporation of America and Gilfillan Corporation, which rank eighty-fourth and ninety-seventh on the list of recipients of Defense contract awards. Respectively, they received awards totaling $\$ 35,000,000$ and $\$ 28,900,000$ during the Fiscal Year in comparison with net sales of $\$ 47,873,483$ and $\$ 39,172,585$ during the Calendar Year. Because of the differences between Fiscal Year and Calendar Year and between awards and net sales these comparisons are valid only as general illustrations. Net sales figures are from Moody's Industrials and contract award figures are from the Department of Defense List of Net Value of Military Prime Contract Awards for Fiscal Year 1962 .

${ }^{13}$ Typical of this view is the following statement of position advanced at the 1962 Convention of the United Automobile, Aerospace and Agricultural Implement Workers (UAW): "The central fact in any realistic appraisal of the aerospace workers' problem-both in Canada and the United States-is the role of government in the aerospace industry. Ninety-five percent of the employment in aircraft and missiles is defense employment. The aerospace industry is almost wholly the creature of government. The forms of private enterprise may be observed; the profits of private enterprise are certainly much in evidence. Representatives of private management face representatives of the UAW and IAM [International Association of Machinists] across the table in aerospace bargaining. Yet the real power over the aerospace industry is the power of the government-and the real responsibility for policies affecting aerospace workers is that of the procurement arm of the government." 50 L.R.R.M. 49 (I962). 
in this light, for its economic position will be so defined. Labor, concerned with the job security of the employees, must formulate its demands in a manner that accounts for future defense action.

This dependence of labor and management on defense may be mutual. Labor and management, for their part, may need a particular defense procurement. The Department of Defense, for its part, may equally need the particular product. Not all goods purchased by the Department of Defense are readily obtainable in the market place. It procures the defense of the nation, the defense, indeed, of the free world. When a complex weapons system is involved, the department cannot immediately turn to another producer for an equivalent product. The choice among weapons systems is an exceptionally difficult one, requiring the most painstaking of military, scientific, and economic judgments. Years of preparation precede production of a selected system. More years may well be necessary before another producer could be substituted, or even added. The Department of Defense cannot wait. Like labor and management, it too may feel a dependence.

Because other government departments and agencies are primarily concerned with labor policy, the basic philosophy of the Department of Defense is and has always been to leave labor matters to the interested civilian agencies. ${ }^{14}$ From the directives establishing defense policy to the daily administrative details, this philosophy prevails. It prevailed in the military departments before the Department of Defense was established. ${ }^{15}$ Labor problems associated with the contracting process accordingly are remitted to the civilian agencies. The Department of Defense may have the procurement responsibility, but resolution of any associated labor problems is their mission.

At the same time, when labor problems threaten the defense of the nation, the capacity of the Department of Defense to perform its mission is drawn into question. Remission to the civilian agencies must then withstand pragmatic appraisal. Philosophical propriety is not enough.

The Defense response to labor problems has varied markedly in the course of time. Always is it unified, however, by the dictates of the defense mission. The interest in production-defined in intensity by the mission-is the touchstone of defense responses to problems of labor policy. A review of these responses is instructive to an appreciation of the current situation, which involves effective civilian agencies functioning within an established national labor policy. Such a review lends itself to separate treatment of three facets of labor policy: labor standards or practices, labor disputes, and labor supply. For convenience, the history of defense responses prior to the establishment of the Department of Defense will be confined to the War Department.

\footnotetext{
14 See also, ASPR I2-Iox.I(d), 32 C.F.R. § r2.xox-r(d) (Supp. 1963), which provides that "Each Department shall remain impartial in and shall refrain from taking a position on the merits of a dispute as between labor and private management."

${ }^{15}$ Act of July 26, 1947, 61 Stat. 495.
} 


\section{Labor Standards or Practices}

The defense experience in the area of labor standards or practices has been bound up with the field of labor disputes as well. Understandably. Labor standards and practices regularly are the subject of labor disputes.

Questions of labor standards are also related to problems of labor supply. A prohibition against discrimination, for example, provides a supply of workers who otherwise might not have been employed.

The present-day government contract contains a number of provisions governing labor standards or practices. Nondiscrimination in employment opportunity on the basis of race, creed, color, or national origin is affirmatively undertaken by the contractor, who also agrees to require the same efforts of his subcontractors. ${ }^{16}$ Use of child labor, and convict labor, is forbidden by the contract. ${ }^{17}$ Once employed, laborers and mechanics must be paid at least time and one-half for work in excess of eight hours per day or forty hours per week. ${ }^{18}$ Additionally, construction workers must be paid prevailing wages and receive their full pay without unauthorized deductions. ${ }^{19}$

${ }^{10}$ Exec. Order No. I0925, 26 Fed. Reg. 1977 (I96I). After declaring that discrimination is contrary to the constitutional principles and policies of the United States and that it is in the general interest and welfare of the United States to utilize all available manpower efficiently and effectively, the order establishes the President's Committee on Equal Employment Opportunity to carry out its policies and purposes. The order requires government contractors and subcontractors to state the essence of their agreement not to discriminate in advertisements for employees, to advise labor unions representing their employees, the employees themselves and applicants for employment of the contractor's undertaking, and to abide by rules and regulations including compliance reporting requirements established by the order and the Committee. The order provides substantial enforcement powers including the use of judicial injunctions and criminal proceedings where proper, in addition to termination of existing contracts and bar of future contract awards.

${ }^{17} \mathrm{~A}$ general prohibition against the use of convict labor by government contractors is provided by an I887 statute, 24 Stat. $4 \mathrm{II}$, as revised, 62 Stat. 703, I8 U.S.C. $\$ 436$ (1958), and by Exec. Order No. $325 \mathrm{~A}$ of May 18, 1905. The Walsh-Healey Public Contracts Act repeats the prohibition and prohibits child labor as well. 49 Stat. $2036-39$, as amended, 4I U.S.C. $\$ \$ 35-45$ (I958). Child labor prohibitions do not apply to contracts for construction, research and development, and other purposes not covered by Walsh-Healey. This hiatus is more theoretical than real in light of the comparable child labor standards of the Fair Labor Standards Act, which broadly applies to employees engaged in interstate commerce and applicable statutes in each of the 50 states.

${ }^{18}$ Walsh-Healey Act, $\S \mathrm{I}(\mathrm{c}), 49$ Stat. 2036 (1936), as amended, 5 U.S.C. $\S 6 \mathrm{I} 6$ (I958); Contract Work Hours Standards Act $\$ 102$ (a), 76 Stat. 357 (I962), 40 U.S.C. $\$ \$ 327-32$ (Supp. IV, I962).

${ }_{10}$ Davis-Bacon Act, 46 Stat. I 494 (I93r), as amended, 40 U.S.C. $\$ 276 a$ (1958). Under the provisions of this act the Secretary of Labor determines the prevailing wage for each classification of laborer or mechanic to be employed on a government contract in a given locality, 29 C.F.R. $\$$ I.I-12 (1963). The wage so determined is set forth as an obligation in the government contract. E.g., ASPR XII, Part 4. Enforcement of the obligation is accomplished primarily by the contracting agency but significant responsibilities rest with the Secretary of Labor under the act and Reorganization Plan No. 14 of 1950,64 Stat. 1267,5 U.S.C. $\$ 1333$ (1958), and with the Comptroller General under the act and under his general supervision over the expenditure of funds appropriated by the Congress. The Copeland Act, $\S$ Io(b), 48 Stat. 948 (I934), as amended, 40 U.S.C. $\$ 276 \mathrm{c}$ (I958), and the Anti-Kickback Act, 62 Stat. 740 (1948), I 8 U.S.C. $\$ 874$ (1958), contain the prohibitions against unauthorized deductions. To induce any person to give up any part of his compensation in violation of these provisions is a criminal rather than civil offense and is subject to fines up to $\$ 5,000$ and imprisonment up to five years.

The Walsh-Healey Act requires payment of the prevailing minimum wage in manufacturing contracts, but, unlike construction, the wage itself is not expressed in the contracts, but rather is published in the 
Each of these contractual requirements is buttressed by statute or executive order. Their presence in government contracts is largely a matter of enforcement technique.

It was not always so. The War Department utilized its contracting power to require similar standards and practices in the absence of statute or executive order expressing national policy.

An early-and good-illustration was the creation of the Cantonment Adjustment Commission. In late May of I9I7, plans for sixteen Army cantonments comprised the largest building program the nation had ever undertaken, and under the time pressures of a World War. Any loss of time occasioned by labor disputes simply could not be tolerated.

Responding to this need-in advance of the construction-the Secretary of War entered into an informal agreement with the president of the American Federation of Labor which gave birth to the Cantonment Adjustment Commission. That agreement, dated June I9, turned the matter of wages, hours, and conditions over to the Commission, and provided that it "shall use the union scales of wages, hours, and conditions in force on June $\mathrm{x}, \mathrm{I} 9 \mathrm{I} 7$, in the locality where such [each] cantonment is situated."20 The Commission was tripartite in composition, with membership from labor, management, and the public. As prevailing standards rose, the Commission, as was envisioned by the agreement, provided for the increase in the particular project. Never was its decision challenged by either side. As a result, the program was completed without labor difficulties. The Commission's jurisdiction was extended to all construction work of the War Department and, later, to the Navy as well. Its success was unquestioned.

A similar technique was adopted for Army clothing, where the problem of labor standards was more acute. In this context, interestingly, neither labor disputes nor labor supply formed the basis of the action. With the need for uniforms greatly increased, War Department contracts began to be awarded to firms that maintained sweatshop conditions. Apart from generalized interest in the treatment of the industrial manpower that was necessary to support the Army, two aspects of this

Federal Register. This is largely explained by the fact that the Walsh-Healey rate regularly is industry wide, while the Davis-Bacon rates are individually determined by project. Sec note 22 infra.

20 The full text of the agreement was:

"For the adjustment and control of wages, hours, and conditions of labor in the construction of cantonments, there shall be created an adjustment commission of three persons, appointed by the Secretary of War; one to represent the Army, one the public, and one labor; the last to be nominated by Samuel Gompers, member of the Advisory Commission of the Council of National Defense, and president of the American Federation of Labor.

"As basic standards with reference to each cantonment, such commission shall use the union scales of wages, hours, and conditions in force on June 1,1917 , in the locality where such cantonment is situated. Consideration shall be given to special circumstances, if any, arising after said date which may require particular advances in wages or changes in other standards. Adjustment of wages, hours, or conditions made by such boards are to be treated as binding by all parties."

"Newton D. BAKER

SAML. GOMPERS"

U.S. War Dep't, Office of Secretary, A Report of the Acttvithes of the War Department in the Field of Industrial Rezations DuRing the War 72 (IgI9) [hereinafter cited as War Dep'T REPORT]. 
development were of specific concern to the War Department. First, it was intolerable to have uniforms made in any fashion which would allow the transfer of contagious germs from sweatshop workers to military personnel. Second, delivery dates were not regularly being met because of the presence of irresponsible and incompetent contractors. The solution to these problems was the creation of the Board of Control for Labor Standards in Army Clothing, later reduced to a single Administrator. This Board was not tripartite-a severe jurisdictional dispute in the industry preventing selection of a labor representative. ${ }^{21}$

The Board accomplished its mission through use of a qualified bidders list with continuing inspection of contractor facilities. Armed with a list of prospective bidders, the Board conducted preliminary inspections and found qualified only those contractors who maintained satisfactory conditions, complied with state labor laws, and had proper protection against fire. Prospective bidders who failed to qualify were advised of necessary changes and upon making those changes were later qualified. A continuing inspection was also maintained. Additionally, when disputes arose, the Board tendered its good offices for mediatory assistance.

Labor standards were also set by the board technique for contracts for harness and saddlery during World War I. The National Harness and Saddlery Adjustment Commission was established on a tripartite basis in response to a feared general strike of the entire industry. Its jurisdiction was defined to include future disputes for the duration of the war. Contrary to the Cantonment Adjustment Commission, the commission in this industry set nationwide rates, a distinction between construction and manufacturing that inheres in the nature of the work and that has persisted under the later enacted wage-setting statutes. ${ }^{22}$

${ }^{31}$ The Amalgamated Garment Workers Association (AGWA) led by Sidney Hillman had seceded from the American Federation of Labor (AFL) and was regarded as an outlaw independent union competing with the United Clothing Workers of America (UCWA), the AFL affliate. The dispute between the two unions was irreconcilable even in the face of War Department efforts to achieve an understanding between them. The Secretary of War adopted a policy of strict impartiality between the two organizations and in keeping with this policy declined appointment of anyone associated with either organization to deal with controversies arising in the manufacture of Army clothing. The conflict was crystallized in a case involving Mark Cowan and Company. Cowan's employees, members of the AGWA, struck and alleged to the Board of Control that Cowan was not maintaining hours and working conditions as required by the Board. When the Board sought to resolve the dispute with Cowan, the latter responded that it had an agreement with the UCWA and would operate its plant with members of that organization in accord with the Board's requirements. The Board endeavored to hold a hearing to resolve the dispute but Cowan refused to participate. The Board countered by refusing to certify Cowan as an acceptable contractor until it submitted to its jurisdiction. In due course the contractor complied and the controversy was adjusted. The adjustment, however, was in essence a Pyrrhic victory since Cowan in the intervening time had manned his factory completely with UCWA workers and the striking AGWA members had obtained other employment. WAR DEP'T REPORT, op. cit. supra note 20, at I7-rg.

${ }^{32}$ Thus wage determinations for construction work under the Davis-Bacon Act are based upon rates found on similar projects in the city, town, village, or other civil subdivision of the state in which the work is to be performed $(\S x)$ whereas those for the industries covered by the Walsh-Healey Act are derived from the wages "for persons employed on similar work or in the particular or similar industries or groups of industries currently operating in the locality" in which the contract is to be performed $(\$ x(b))$. The reference to "locality" in the Walsh-Healey Act comprehends industry-wide standards. In a given case, this may result in a single nationwide rate. Covington Mills v. Mitchell, 229 F.2d 506 (D.C. Cir.), cert. denied, 350 U.S. 1002 (1955). 
Established as minima, the rates fixed by the National Harness and Saddlery Adjustment Commission soon became maxima as well, thus completing the total control of wages in the Commission. In an industry that was otherwise on the decline, the magnified demands of the War Department resulted in a keen competition for workers, with a consequent upward influence on wages and an attending potential increase in costs to the War Department. The Commission responded by ruling that its standard wages could not be exceeded by contractors.

The Commission also set hours, so complete was its control. With the ruling that the standard wages constituted a ceiling as well as a floor, the competition for workers shifted to hours. Contractors sought to attract workers by offering longer hours, and hence larger earnings. The Commission responded by setting a maximum on hours of work, subject to exception only upon its grant of special authority.

Other actions were taken by the War Department directly, without the establishment of a board. It was during the first World War that the Supreme Court held the federal child labor law unconstitutional. ${ }^{23}$ The War Department promptly required the same prohibition in its contracts. The industrial army essential to the war effort was not to be composed of children.

Similarly, the War Department controlled the maintenance or relaxation of state labor standards that were already established. State legislation by the outbreak of the war regulated hours of work, the employment of women and children, sanitary facilities and the like. The War Department maintained relations with the various state agencies charged with enforcement of this legislation, adopted a policy that the existing standards should not be relaxed except in an emergency, and centered in itself the power to determine when relaxation was proper. Under this arrangement, there were no general relaxations and the specific ones were comparatively few and of limited duration.

The philosophy underlying all of these World War I actions was simple: the efficient and effective conduct of war. A memorandum of suggestions for arsenal commanders and manufacturers, issued by the Chief of Ordnance, sums it up well:

In view of the urgent necessity for a prompt increase in the volume of production of practically every article required for the conduct of the war, vigilance is demanded of all those in any way associated with industry lest the safeguards with which the people of this country have sought to protect labor should be unwisely and unnecessarily broken down. It is a fair assumption that for the most part these safeguards are the mechanisms of efficiency. Industrial history proves that reasonable hours, fair working conditions, and a proper wage scale are essential to high production. During the war every attempt should be made to conserve in every way possible all of our achievements in the way of social

${ }^{28}$ The Keating-Owen bill of September $\mathrm{r}, \mathrm{rgr} 6, \mathrm{ch} .432,39$ Stat. 675 , prohibited interstate shipment of products of establishments in which children below specified minimum ages were employed. The law became effective one year after passage and its enforcement was enjoined almost immediately. The injunction was appealed ultimately to the Supreme Court which then sustained the injunction and declared the act unconstitutional. Hammer v. Dagenhart, 247 U.S. 251 (19I7). This position, of course, was specifically overruled when the constitutionality of the Fair Labor Standards Act of 1938 was upheld. United States v. Darby, 3 I2 U.S. roo (1940). 
betterment. But the pressing argument for maintaining industrial safeguards in the present emergency is that they actually contribute to efficiency. To waive them would be a shortsighted policy, leading gradually but inevitably toward lowered production. It might be expected that an individual working ro hours a day instead of 8 , or II hours a day instead of ro, would turn out more goods. He can, and doubtless will, for the first few days. But experience shows us that in a few weeks, or a few months, the output will be the same, or even less, than it was during the shorter day.

This department, procuring war material in great quantities and of many different kinds, can not be without interest as to the conditions under which this material is manufactured. In peace time we can afford to depend upon routine agencies for seeing to it that those engaged on Government work are both reasonably efficient and fairly protected in the conduct of their work. There is grave danger, however, that under stress of war such consideration may be overlooked, and that not only injustice may be done to individual workers and groups of workers but that quantity and quality production may itself suffer. ${ }^{24}$

As the War Department emerged from World War I, its concern with labor problems-no longer requiring action to assure production-was taken up with planning. ${ }^{25}$ Continuing efforts were made to develop an industrial mobilization plan for use in a future war effort. And while successive plans were drafted, no plan was ever adopted. World War II, with its urgency, arrived in the absence of an accepted plan. ${ }^{26}$

World War II presented the War Department with a far different context of labor standards and practices. The locally prevailing wages requirement for construction that had been administratively born in the Cantonment Adjustment Commission was now a statutory command of the Davis-Bacon Act. ${ }^{27}$ The safety and health concerns of the Board of Control for Labor Standards were largely embodied in the Walsh-Healey Act, as was the prohibition against child labor that formerly existed only in contract clauses. ${ }^{28}$ The Walsh-Healey Act also embraced the wage-setting features for manufacturing that had previously been the work of the National Harness and Saddlery Adjustment Commission. ${ }^{29}$ The bulk of the problems that had triggered these three major administrative efforts-and accomplishments-of World War I were not so open to executive action in World War II. Legislation had taken up where administration stopped.

Legislation had, indeed, gone further. The Wagner Act had been enacted. ${ }^{30}$ Guaranteeing employees the right to join unions, to bargain collectively, and to

"General Orders No. 13, Nov. 15, I9I7, Office of The Chief of Ordnance, U.S.A., Suggestions for Arsenal Commanders and Manufacturers.

${ }^{25}$ For a more extensive discussion of the role of the War Department in labor matters in World War I, see WAR DEP'T REPORT, op. cit. supra note 20 , which furnishes the basis for the history of that period discussed in this article.

${ }^{30}$ Byron Fairchild \& Jonathan Grossman, The Army and Industrial Manpowar 3-20 (I959). Much of the material on which the World War II discussion in this article is based was obtained from this worthwhile history.

${ }^{27}$ See note Ig stipra.

${ }^{38}$ See note I7 supra.

${ }^{20}$ See note 22 supra.

${ }^{30}$ Act of July 5, 1935, ch. 372, 49 Stat. 449-57. 
engage in concerted activities in furtherance of collective bargaining, the act also proscribed certain employer actions as unfair labor practices.

Unlike Davis-Bacon and Walsh-Healey, the Wagner Act made no provision for government contracts. Whereas the two former required compliance clauses in the contracts-and, moreover, applied only to government work-the latter applied to industry generally and was silent on government contracts.

A major labor issue on military contracts prior to our entering the war was, as a result, enforcement of the Wagner Act. Positions were taken on both sides of the question whether or not companies that did not comply with the act should be denied contracts. ${ }^{31}$ After some vacillation, the matter was finally resolved that the War Department should not enforce the act through contract actions. The labor relations practices of a prospective contractor were a matter to be considered, it was agreed, but only one among many. Contracts had to be awarded in furtherance of the interest in production necessary to the effective waging of war. In any event, by the time the issue was settled, the President had declared an unlimited national emergency. ${ }^{32}$ The company whose juxtaposed Wagner Act violations and contract awards had particularly aggravated the argument had been successfully organized and had concluded a collective bargaining agreement which provided for a union shop and a wage scale matching the highest in the industry. ${ }^{33}$ The issue had become less pressing. ${ }^{34}$

The responsibility for wage rates and labor disputes exercised in World War I by the Cantonment Adjustment Commission, the Board of Control for Labor Standards in Army Clothing, and the National Harness and Saddlery Adjustment Commission was in World War II the task of the National War Labor Board. Tripartite in composition, and based on the voluntary abandonment of economic force by

s1 The Department of Interior attempted to deal with this issue by requiring vendors to certify to compliance with the Wagner Act in order to obtain payment under its contracts. Upon refusal by a contractor to execute such a certification, the question of its propriety was submitted to the Comptroller General who, after ruling that there was no authority to require compliance with the Act as a condition precedent to the award of a contract concluded: "there likewise would appear no proper or legal basis for requiring as a condition precedent to payment of the contract price . . . that the bidder certify that it complied with the National Labor Relations Act in the performance of the contract." 20 Decs. CoMp. GEN. I4 (I940).

${ }^{32} 6$ Fed. Reg. $26 I_{7}$ (I94I). In this Proclamation, the President said, "I call upon all of our loyal workmen as well as employers to merge their lesser differences in the larger effort to insure the survival of the only kind of Government which recognizes the rights of labor or of capital."

${ }^{33}$ FaIrchild \& Grossman, op. cit. supra note 26 , at 43 .

8t The issue has not disappeared, though, and is still raised today. The opinions of the Comptroller General on the subject, however, suggest that legislation would be required for a different result. I7 Decs. Comp. Gen. 37 (1937), cited with approval at I8 id. 285, 294 (1938), 19 id. 748, 750 (1940), 20 id. $14,14-15$ (1940) and 33 id. 477,479 (1954). See also note 31 stipra. At least two efforts have been made to secure legislation but in both instances the bills were not reported out of Committee. The first attempt was in 1938 (S. 3390, Feb. 4, r938, and H.R. 9745, March 4, 1938, 75th Cong., 3d Scss.), and the second in 1955 (S. I760, April 20, I955, H.R. 6592, June 1, 1955, and H.R. 666r, June 6, 1955, 84 th Cong. Ist Sess.). Although general legislation of this type has not been adopted the Bituminous Coal Act of 1937 provided for the denial and/or cancellation of government contracts with employers subject to the act who denied their employees the right to organize and to bargain. Act of April 26, 1937, $\$ 9$, 50 Stat. II 87 . 
labor and management, the National War Labor Board was created by the President, not the War Department. ${ }^{35}$ Special supplementary commissions this time were not undertaken by the War Department. Although the executive order creating the War Labor Board envisioned that its decisions would be binding on the parties to any dispute it considered, no provision was made for enforcement machinery. ${ }^{36}$

Not surprisingly, enforcement of War Labor Board dẹcisions was viewed differently from the Wagner Act. Denial of contracts to companies in non-compliance with the Wagner Act could mean loss of the opportunity to obtain a needed product. War Labor Board decisions, on the other hand, were designed to end disputes that otherwise threatened to interrupt production. Seizure was accordingly relied upon to enforce the Board's decisions and also those of a short-lived predecessor, the National Defense Mediation Board. ${ }^{37}$ Seizure was the technique whether labor or management was the intransigent party. ${ }^{38}$ Where the company involved was engaged in essential work for the war effort, War Department enforcement of the Board's decision was immediately in furtherance of the critical interest in continued production. In those few instances in which the company was not engaged in essential war work, seizure was necessary to protect-and conclusively establish-the foundation of the War Labor Board: resolution of labor disputes without interruption of work and operations. ${ }^{39}$ Should that foundation have been allowed to become infirm in an instance involving non-essential production, the life blood of the Board could have been spilled in an essential case. The question about enforcement of decisions of the National War Labor Board-unlike the Wagner Actadmitted of only an affirmative answer.

In time, the War Labor Board was charged with wage stabilization, as is brought out in the succeeding section of this article, and its jurisdiction was extended beyond disputes. ${ }^{40}$ Although the control over labor standards thus exercised by the government was extensive, the role of the War Department was largely confined to enforcement. Labor standards and practices were taken up by specially created agencies such as the War Labor Board but they were civilian agencies.

Similarly today, the Department of Defense plays a minimal role in the field of

${ }^{35}$ Exec. Order No. 9017, 7 Fed. Reg. 237 (1942).

${ }^{30}$ See text at note 53 infra.

37 There were three seizures involving the National Defense Mediation Board: North American Aviation, Inc., Federal Shipbuilding and Drydock Company, and Air Associates, Inc. In North American, the seizure resulted from a union refusal to continue work and operations while the Board disposed of the case. The other two seizures resulted from the companies' refusals to accept the Board's recommendations. National War Labor Board, Termination Report 20 (i947).

${ }^{38}$ Under the National War Labor Board, there were 40 seizures. Id. app. J-39(a).

${ }^{30}$ The capacity of the United States to do so was tested by Montgomery Ward and Company, 150 F.2d 369,380 (7th Cir. 1945). In affirming the President's power to seize, the court ruled: "It matters not whether this group [of employees] is actually engaged in making articles needful in the War or in distributing such articles among those engaged in essential war industry." This decision was bottomed on the War Labor Disputes Act. The power of the President to take such action solely through his powers as Commander-in-Chief was also argued in that case but was left undecided. Subsequently in 1952 it was decided by the Supreme Court that at least in time of peace, the President has no such inherent powers. Youngstown Sheet and Tube Company v. Sawyer, 343 U.S. 579 (1952).

${ }^{10}$ See text at notes $54-57$ infra. 
labor standards and practices. The Davis-Bacon and Walsh-Healey acts remain in force, requiring the payment of prevailing wages in both construction and manufacturing. The former is enforced by the Department of Defense as a contracting agency, the latter by the Department of Labor under the specific provisions of the statute itself. The Taft-Hartley Act has succeeded the Wagner Act and, like its predecessor, is not enforced by the Department of Defense-non-compliance remains one of many factors to be considered in determining whether or not production demands can be met. ${ }^{41}$ The Federal Mediation and Conciliation Service is charged with responsibility for disputes affecting commerce, thus covering much the same ground as the National War Labor Board. Its efforts are strictly mediatory, however, and so no question of enforcing decisions has arisen. ${ }^{42}$

In one area-determinations of cost allowability-the Department of Defense does specifically address itself to labor standards or practices. Cost type contracts do not guarantee the contractor recoupment of all his costs. The reasonableness of the various costs incurred must be established. When the cost is associated with a labor standard or practice, the determination of reasonableness by the Department of Defense inevitably involves a judgment on the particular standard or practice. ${ }^{43}$

The influence that these cost allowability decisions exert on the private labor management relationship is minor. True, contractors are likely to eschew agreeing to labor demands for standards or practices that have been or could be expected to be ruled unreasonable and disallowed wholly or partially for purposes of cost reimbursement. On the other hand, labor standards and practices are not made up of whole cloth, and Defense decisions on allowability for cost purposes are also not reached in a vacuum. Trends in industrial practice can be discerned and weighed in the process of determination. The effort to make cost decisions reflective rather than dispositive of industrial customs and trends is well illustrated by problems involving missile and space sites. Cost reasonableness as well as labor disputes at missile and space sites fall within the jurisdiction of the Missile Sites Labor Commission.4 Composed of representatives of labor, management, and the public, and chaired by the Secretary of Labor, with the Director of the Federal Mediation and Conciliation Service serving as Vice Chairman, the Commission advises the Department of Defense on the reasonableness of costs associated with labor. Since the advice is based on what prevails in the private sector, and given by persons particularly knowledgeable in that regard, the defense influence is held to a minimum.

Determinations of cost allowability are inherent in the contracting process; the

11 See note 34 supra.

42 When the Railway Labor Act is involved, the relevant agency is, of course, the National Mediation Board. See text at notes 6-7 supra. Its efforts, in this context, are also mediatory. See also text at note 6 infra.

${ }^{43}$ See ASPR I5-205.6, 32 C.F.R. $\$$ I5.205-6 (I96I) (Compensation for Personal Services); 15-205.10, 32 C.F.R. $\$ 15.205-10$ (I96I) (Health and Welfare Costs); 15-205.18, 32 C.F.R. \$ I5.205-18 (1961) (Labor Relations Costs); $15-205.25,32$ C.F.R. $\$$ I5.205-25 (Overtime); 15-205.33, 32 C.F.R. $\$ \times 5.205-33$ (I96I) (Recruiting Costs); I5-205.39, 32 C.F.R. $\$ 5.205-39$ (I96I) (Severance Pay).

"Exec. Order No. 10946, 26 Fed. Reg. 4629 (I96r). 
other military involvements in labor standards and practices traced in this review went beyond the administrative aspects of the contract to the fundamental interest in obtaining the purchased production. Not only must the Defense Department perform its mission within its budget and without waste of public funds, not only is pursuit of economy an essential attribute of contracting authority, but, most simply, the use of cost-type contracts by definition requires cost decisions. Labor standards and practices become relevant as cost items that must be reviewed with the rest. The other military concerns with labor standards and practices were more intimately bound up with the mission of defending the nation. Certainly this was so when essential production was threatened by labor disputes. But even beyond disputes, as with the Board of Control for Labor Standards in Army Clothing, labor standards and practices could affect production and thus trigger the most critical of defense interests. The intensity of this interest was understandably high in World War I, and so the War Department was quite active in the field of labor standards. With the lessened intensity of the period between World War I and World War II, a plan for industrial mobilization could not be adopted. World War II ushered in a new era of criticality, but legislation had created a framework for action. In addition, the response of civilian agencies was more immediate, more pervasive, and more effective. Similarly, at present, the civilian agencies perform a broader and more significant role. Whether the urgency be defined by hot war, cold war, or peace, the Defense need for production to perform its mission is paramount; the requirement for defense action to that end depends not only on the criticality of the product but on the civilian response as well.

II

\section{Labor Disputes}

If labor standards or practices sometimes threaten production, strikes and lockouts always do. The Department of Defense interest in labor disputes, necessarily, is resolution without interruption of work and operations. The intensity of this interest varies with the importance of the particular contract. ${ }^{45}$ Missiles and shoes, bullets and socks, raise different issues of criticality.

When the contract is critical, when essential production is involved, the defense interest is of the highest magnitude. Battles cannot be postponed, wars cannot be won, until the necessary weapons reach the battlefield. The military must be equipped and ready. Disputes that delay the needed readiness must be ended. The enemy does not grant an extension of time by reason of labor difficulties in the industrial army.

This interest and the established policy of remitting labor problems to the civilian agencies are not inconsistent. To be interested in the end does not require participation in the means. Only when other means are lacking or inadequate does devotion to the end overcome reluctance at engaging in the means.

${ }^{25}$ See ASPR I2-10Ie, 32 C.F.R. I2.10I(e) (I96I). 
Thus it was in World War I. The accepted policy was that labor matters were the province of the Department of Labor; the War Department would simply channel problems affecting its contractors to the Labor Department for adjustment through its Conciliation Service.

The program for building cantonments was too large and too critical, however, to risk waiting until disputes actually arose and strikes occurred. So the Cantonment Adjustment Commission was created. By the same token, the threatened industrywide strike in harness and saddlery could not be allowed to take place, so great was the need for uninterrupted and expanded production. So the National Harness and Saddlery Commission was established. And the contagion and non-delivery prob. lems in military clothing existed whether or not a labor dispute would develop. So the Board of Control for Labor Standards was born.

Still, the War Department clung to its basic philosophy that labor problems should be resolved by the Department of Labor. The three boards were, it was true, exceptions; but the basic philosophy remained the standard.

It soon developed, however, that contractors were less cooperative with representatives of the Department of Labor than they were with War Department personnel. Manufacturers tended to think of the Department of Labor as a peacetime mediation activity which tendered good offices that they could accept or reject at will.

As a result, the War Department was drawn more broadly into the business of resolving labor disputes. In munitions, the Ordnance Department set up an Industrial Service Section, which plunged fully into the field of adjusting disputes. It mediated, arbitrated, and generally did whatever was necessary to bring about a resolution. The Conciliation Service of the Department of Labor adopted a policy of avoiding participation whenever the Ordnance Department assumed jurisdiction of a dispute.

When the Industrial Service Section was not able to effect a resolution, it referred the matter to the National War Labor Board. Set up by the Secretary of Labor and proclaimed by the President, the War Labor Board had no enforcement power. ${ }^{40}$ The War Department provided it.

Two extreme cases tested the machinery so established. Both were referred to the National War Labor Board. In one, the workers-contrary to the urging of their union-refused to accept the decision. The President wrote a public letter to the striking employees which requested a return to work and acceptance of the award in no uncertain terms:

Therefore, I desire that you return to work and abide by the award. If you refuse, each of you will be barred from employment in any war industry in the community in which the strike occurs for a period of one year. During that time the United States Employment Service will decline to obtain employment for you in any war industry elsewhere in the United States, as well as under the War and Navy Departments, the Ship-

${ }^{46}$ Presidential Proclamation of April 8, x918, 65 Cong., 2d Sess. (I9r8). 
ping Board, the Railroad Administration, and all other Government agencies, and the draft boards will be instructed to reject any claim of exemption based on your alleged usefulness on war production. ${ }^{47}$

The decision was accepted, and the men returned to work.

The other case involved a management refusal to accept a decision. The War Department commandeered the plant and installed the Ordnance Department to operate it. ${ }^{48}$

An Industrial Service Section was also established in the Construction Division. This section functioned much as a scale model of the Cantonment Adjustment Commission, disposing of as many as twenty controversies a day. Major matters were referred to the Commission.

The Quartermaster Corps followed suit. Its Industrial Service Section performed the work of the Administrator of Labor Standards in Army Clothing-the successor of the Board of Control-as well.

Aircraft similarly received special attention. The Aircraft Bureau had its Industrial Service Section, charged with the resolution of disputes involving aircraft contractors.

Perhaps the most aggressive action of the War Department in World War I in the labor area-and certainly the most colorful-took place in the lumber camps of the Northwest which produced spruce essential to the manufacture of airplanes. A strike had occurred and been unsuccessful, the men had returned to work but were engaging in a slow-down, and a renewed strike effort seemed clearly in the offing. An Army colonel was dispatched to the area. He quickly organized the men into

\footnotetext{
\$2 The letter was the culmination of intensive efforts to resolve a dispute which had continued for over a year. It occurred in Bridgeport, Conn., where the Machinists' union was demanding wage increases and adjustments of various grievances. Initially there were efforts to resolve the dispute by local conciliation. These efforts were unsuccessful and a series of strikes resulted in various plants involved in the production of ordnance material. The first effort at resolution by an agency outside of the Bridgeport area was made by an Ordnance Wage Adjustment Board. This Board failed and the Secretary of War referred the matter to the National War Labor Board. Ultimately a decision of the Board umpire was handed down ruling on essentially all aspects of the controversy. The rulings, however, did not meet labor's anticipations and a strike resulted. This strike was deemed to jeopardize not only the production programs affected but also the validity of the decisions of the government agencies dealing with labor controversies. Because of the gravity of the situation the matter was referred by the Secretary of Labor, the Acting Secretary of War, and the Chairman of the National War Labor Board to the President who issued the quoted letter. WAR DEP'T REPORT, op. cit. supra note 20, at 32-34.

${ }^{48}$ Although the dispute initially involved wages only, it grew to significantly larger proportions. The company, Smith and Wesson Company of Springfield, Massachusetts, operated with use of what have since been termed "yellow dog" contracts and responded to wage demands and subsequent union organization efforts by discharging employees involved. These practices continued in the face of a National War Labor Board principle stating: "The right of workers to organize in trade unions and to bargain collectively through chosen representatives is recognized and affirmed. This right should not be denied, abridged or interfered with by the employers in any manner whatsoever." In any event a strike involving about half of Smith and Wesson's employees occurred. Unsuccessful efforts by the War Department to resolve the dispute led to action by the National War Labor Board. The Board in part ordered the acceptance by the company of the principle of collective bargaining. The Company denied the Board's jurisdiction, declined to accept its decision, and indicated willingness instead to have the War Department commandeer the plant. Seeing no alternative, the War Department, with the consent of the President, did just that, dispensing with the services of the company officers and installing Ordnance Department representatives to operate the plant directly. Id. at $34-36,86-89$.
} 
his own Loyal Legion of Loggers and Lumbermen, won the complete confidence of both the men and the operators, and-under authority granted by both sidespromulgated a charter of working conditions that was in turn implemented. Production of the essential spruce went forward..$^{40}$

With the end of World War I, the War Department reverted to its historic policy of non-intervention. Labor problems again were to be the province of the civilian agencies of government.

World War II, as we have seen, involved a greatly changed framework. Legislation had covered much of the ground previously requiring administrative action. In addition, the great concern that defense production not be interrupted by strikes found expression in the creation of new civilian agencies by the President rather than the establishment of special commissions by the War Department.

The first such agency was the National Defense Mediation Board, created by executive order on March I9, I94I..$^{50}$ Tripartite in nature, the Board was composed of four labor members, four management members, and three public members. Individual disputes were to be handled by a three-man panel, one from each representative group. Panels were empowered to hold hearings, find facts, make recommendations for settlement and-with the consent of the parties-provide arbitrators. The Board's jurisdiction was confined to disputes which were certified to it by the Secretary of Labor as threatening defense production and as not susceptible of resolution by the Conciliation Service of the Department of Labor. Thus, the foundation of the Board-the chief vehicle for adjustment of disputes-was previous efforts by the traditional civilian agency in the field.

The National Defense Mediation Board treated all issues in dispute. Its procedure was to concentrate on mediation first and resort to recommendations for settlement only when an adjustment was not forthcoming. While its recommendations were not binding on the parties-as was true of the National War Labor Board in World War I-the overriding concern with continued production led the War Department to seize the few companies that had refused to accept its recommendations. ${ }^{\text {b1 }}$

The Mediation Board was, however, short lived. Its demise was the result of an unusually bitter and highly unpopular dispute involving the mines of the steel industry. The dispute saw two brief shut downs of the mines, a rejected recommendation of the Board accompanied by the resignation of two of its members and another shutdown, and finally a submission of the dispute for binding decision by a special board of arbitrators. ${ }^{52}$ The appointment of the special board-which

$\triangle 0$ Ibid.

${ }^{60}$ Exec. Order No. 87I6, 6 Fed. Reg. 1532 (I94I).

${ }^{61}$ One of the three seizures in support of the National Defense Mediation Board involved an uncooperative union. See note 37 supra.

${ }^{52}$ The dispute involved the demand of the United Mine Workers for a union shop. The recommendation of the Board was against the union shop on the grounds that $95 \%$ of the miners were already union members, the union was capable of organizing the remainder and the union shop clause was not necessary to the security of the miners. While so recommending, the Board went on to suggest that the nonunion miners should voluntarily join the union. The CIO members dissented and resigned 
reached a contrary decision-undercut the Mediation Board's authority. And the two resignations left the Board hopelessly unrepresentative. The Board's usefulness thus ended, a gap existed in the machinery for resolution of disputes.

The decision of the special board of arbitrators, however, was handed down on the day Pearl Harbor was attacked, and the surge of patriotism and national unity that followed made the gap insignificant.

In any event, on January I2, I942, the President issued an executive order creating the National War Labor Board to take up where the Mediation Board stopped. Again tripartite, the War Labor Board had twelve members, equally divided among labor, management, and the public. The chairman was the previous head of the Mediation Board, whose case load was transferred to the Labor Board.

The Labor Board differed from the Mediation Board in two significant respects. First, it was empowered to take jurisdiction sua sponte after consultation with the Secretary of Labor as well as upon his certification. Second, and far more important, the executive order expressly made decisions of the Labor Board binding on the parties. "After it takes jurisdiction, the Board shall finally determine the dispute and for this purpose may use mediation, voluntary arbitration, or arbitration under rules established by the Board." Als3 Although the Board was founded on the voluntary cooperation of labor and management, its grant of powers envisioned arbitration under procedures not agreed to by the immediate parties. No enforcement machinery was provided, however. This gap, as we have noted, was filled by the War Department.

As the war progressed, fears of inflation grew. Reminiscent of the harness and saddlery industry in World War I, contractors tended to compete for needed labor by improving wages. This became a matter of concern to the Board.

The problem of inflation also concerned the President and the Congress. At the request of the President for legislative authority to stabilize living costs, Congress enacted the Emergency Price Control Act in January 1942, giving the President power over prices, ${ }^{54}$ and in October of the same year it expanded that power to include wages and salaries by passing the Economic Stabilization Act. ${ }^{55}$ Promptly upon the expansion, the President empowered the Labor Board to stabilize all wages, whether or not a dispute existed. ${ }^{56}$ And he created the position of Director of Eco-

from the Board. To bring a termination to the strike that resulted, the dispute was submitted to the special tripartite board, whose contrary decision was dissented from by the industry member. However by virtue of prior agreement this decision was final and binding. JOEL SEIDMAN, AMERICAN LABOR From Defense to Reconversion $64-67$ (1953).

${ }^{18}$ See note 35 supra.

EA Act of Jan. 30, I942, ch. 26, 56 Stat. 23.

st Act of Oct. 2, 1942, ch. 578,56 Stat. 765.

${ }^{50}$ Exec. Order No. 9250, 7 Fed. Reg. 787 I (I942). The benchmark for the wage field generally was established by the Little Steel Cases, NWLB Nos. 30, 3I, 34 and 35 , decided July 16, I942. The cases arose out of a union demand for a one dollar per day increase to reflect the increased cost of living experienced since their last general increase in April I94I. The Board, however, found the cost of living increase of $15 \%$ dated from January, r941. Thus the April r94I increase of the steelworkers was included within the $15 \%$, and the Board found a 5.5 cents per hour increase rather than a \$r.00 per day 
nomic Stabilization, whose approval was necessary before any wage increase which the Board considered would require a price increase could be made effective. ${ }^{67}$

The War Department meanwhile worked closely with the responsible civilian agencies and continually impressed upon them the military significance of the various disputes that developed. In addition, it engaged in repeated publicity campaigns to raise workers' morale and promote their interest in continued production. But the process of resolving disputes remained with the civilian agencies, first with the established Conciliation Service of the Department of Labor and ultimately with the specially created-but also civilian-War Labor Board.58 The War Department, of course, enforced Board decisions by seizure.

Following World War II, the overall context again changed. In 1947 , Congress enacted the Taft-Hartley Act. Among its provisions amending the Wagner Act were those providing for the eighty-day injunction of disputes threatening the national health and safety. ${ }^{59}$ Since a strike involving a critical defense industry regularly creates an emergency within the meaning of Taft-Hartley, this legislation has importantly bolstered the traditional policy of leaving disputes to the civilian agencies concerned with labor matters. Taft-Hartley also removed the Conciliation Service from the Department of Labor, giving it increased stature as an independent agency. ${ }^{00}$ The renamed Federal Mediation and Conciliation Service is now the focal point for all disputes affecting commerce. The Department of Labor retains an important overriding interest, constituting as it does the paramount agency for labor policy of the government. When railroads or airlines are involved, the Emergency Board provisions of the Railway Labor Act-staying strikes for a period of sixty daysand the mediatory efforts of the National Mediation Board are triggered. ${ }^{01}$ This

appropriate to bring wages up to date. This decision, the famous Little Stecl formula, provided the foundation throughout the war period for determining "across-the-board" increases to compensate for increases in the cost of living.

${ }^{57}$ See SeIDMan, op. cit. supra note 52, at II6-I7. Within this framework, however, the Board considered that it had considerable latitude (NWLB Rep. 187) and continued to adjust wages to cure maladjustments, inequities, or substandards of living, and to promote the effective prosecution of the War. This continued into March r943. But on April 8, r943, Exec. Order No. 9328, 8 Fed. Reg. 4681 (1943), generally referred to as the "hold-the-line order," limited severely the wage rate increases that the NWLB could thereafter approve. Specifically the order directed NWLB to authorize "no further increase in wage or salaries except such as are clearly necessary to correct substandards of living, provided that nothing herein shall be construed to prevent such agencies from making such wage or salary readjustments as may be deemed appropriate and may not have heretofore been made to compensate, in accordance with the Little Steel formula as heretofore defined by the National War Labor Board, for the rise in the cost of living between January I, I94I and May I, I942. Nor shall anything herein be construed to prevent such agencies subject to the general policies and directives of the Economic Stabilization Director from authorizing reasonable adjustments of wages and salaries in case of promotions, reclassifications, merit increases, incentive wages or the like, provided that such adjustments do not increase the level of production cost appreciably or furnish the basis either to increase prices or to resist otherwise justifiable reduction in prices."

${ }^{68}$ For a comprehensive review of the development of special civilian agencies and the surrounding context, see SEIDMan, op. cit. supra note 52.

52 Stat. 1062 (I938), as amended, 29 U.S.C. $\$ 206$ (I958).

${ }^{60} 6$ I Stat. I53 (1947), as amended, 29 U.S.C. $\$$ I72 (1958).

${ }^{61} 44$ Stat. 586 (1926), as amended, 45 U.S.C. $\$ 160$ (1958). These provisions call for the appointment of an Emergency Board which must report to the Prcsident within 30 days. The status quo must be maintained pending submission of the report and for 30 days thereafter. 
framework leaves little room-and the effectiveness of these agencies little need-for any departure by the Department of Defense from its established non-intervention policy.

Occasionally, ad hoc procedures may be invoked, as in the recent boards set up to aid in the resolution of disputes affecting the aerospace industry, which of course is heavily oriented toward defense work. These boards, however, were established by the President, not the Defense Department, and on the recommendation of the Secretary of Labor and the Director of the Federal Mediation and Conciliation Service. $^{62}$

In one area, a board has been established on a continuing basis-the Missile Sites Labor Commission. Again, this was done by the President on the recommendation of the Secretary of Labor. The special criticality of the nation's missile and space sites-and the massive nature of the task of activating them-required the creation of a Commission that was particularly equipped to aid in securing uninterrupted and economical work and operations. In a sense, the Missile Sites Labor Commission is analogous to the Cantonment Adjustment Commission. Missile and space sites constitute a discrete, massive, and time-conscious program much as the building of cantonments did. Both commissions were designed to aid in the resolution of disputes based on the voluntary cooperation of the parties. But where the Cantonment Adjustment Commission set wages, the Missile Sites Labor Commission advises on the reasonableness of rates set by the parties themselves. And, as noted, the Missile Sites Commission derived from the recommendation of the labor arm of the government, not the military as with the Cantonment Commission.

The Missile Sites Labor Commission has recommended a standardization of compensation practices in two locations, both of which were put into effect through contract clauses. ${ }^{63}$ At Cape Kennedy and the Mississippi Test Facility, labor and management negotiated project stabilization agreements, providing for standardized practices and the peaceful resolution of disputes. Designed to promote economy and industrial stability on two particularly critical sites, these agreements facilitated the national defense. Accordingly, the Deputy Secretary of Defense and the Administrator of the National Aeronautics and Space Agency invoked the War Powers Act, authorizing the money provisions of the agreements to be specified in government contracts and hence required of all construction contractors. ${ }^{64}$ The primary goal

\footnotetext{
02 The President established two such Boards. One, with George W. Taylor as Chairman, was appointed on July $21, x_{9} 62$ to assist the Aerospace Industry negotiations generally. The dispute involving the Bocing Company was not included in this group and was handled by a second board appointed Sept. 13, 1962 with Saul Wallen as Chairman. The Taylor Board submitted reports including recommendations to the President on Sept. I and Ir, I962. With the exception of Lockheed, the companies and unions accepted the Board Recommendations. The Lockheed dispute, however, continued and by Exec. Order No. I I068, I8 Fed. Reg. 4939 (Ig62), the President appointed a Board under the Taft-Hartley Act to forestall a strike. The Boeing dispute was similarly not resolved by the ad hoc board appointed in that case and a Taft-Hartley Board was appointed under Exec. Order No. x1078, 29 Fed. Reg. 679 (I963). In both cases the parties negotiated settlements while the injunctions were in effect.

${ }^{03}$ E.g., ASPR I2-403.5, 32 C.F.R. I2.403-5 (Ig6I).

oh The determinations enabling the inclusion of the money provisions in government contracts were
} 
of uninterrupted production was thus sought, with the added benefit of increased economy in the compensation practices themselves.

Apart from these cases involving the War Powers Act, a series of Comptroller General decisions has constricted the Defense Department's capacity to use its contracting authority with a view toward resolving labor disputes. The keystone of all procurement is competition. Whether a contract is awarded by bidding or negotiation, the selected contractor has prevailed in a competition. If the competition does not revolve around price, it nonetheless involves cost. As the watchdog over the appropriations of the Congress, the Comptroller General must insure that the executive branch does not misspend money made available by the legislature. ${ }^{05}$ In one case after another, he has ruled that contractual provisions on a variety of labor matters are not proper, either because they increase cost directly by requiring contractors to undergo greater expenditures or because they threaten to do so indirectly by restricting the range of potential contractors and thus narrowing the competition. ${ }^{66}$

Within this overall framework, the matter of labor disputes becomes for the Department of Defense essentially a question of capacity to perform. Like compliance with the Wagner Act, labor disputes are one factor to be considered in determining whether or not production will be forthcoming. If a prospective contractor cannot perform by reason of labor disputes, obviously he cannot be awarded a contract. There is nothing magic about labor disputes in this regard. Anything that renders a prospective contractor unable to perform must disqualify him. ${ }^{07}$ It would be an act of gross irresponsibility to award contracts that would not be performed. The fact that a prospective contractor is currently undergoing a strike does not, however, establish that he is unable to perform. The strike may not be effective, and the company may consequently be able to perform. Whatever the desirability of dealing with struck firms from a labor policy point of view, the critical question of performance must be answered. Production not labor policy is the interest of procurement. Cost not labor policy is the command of the Comptroller General.

Once a contract has been awarded, a strike raises a number of considerations. Three basic problems are involved. First, it must be determined whether or not

made pursuant to Act of Aug. 28, I958, 72 Stat. 972, 50 U.S.C. $§$ I 43I (1958) as implemented by Exec. Order No. 10789, 23 Fed. Reg. 8897 (1958). The essential ingredient of these determinations is that the action taken was "determined necessary in order to facilitate the national defense." Determinations were made by the Deputy Secretary of Defense Sept. 2I, I962, and the Administrator of NASA, Sept. 26, 1962 for Cape Kennedy, and by the Administrator of NASA Sept. 26, 1963 for the Mississippi Test Facility.

${ }_{42}^{6}$ Stat. 25 (I92I), 3I U.S.C. $\$ 53$ (1958).

${ }^{00}$ Rulings of the Comptroller General have prohibited contracting agencies from requiring as a condition of a government contract that the contractor comply with the National Labor Relations Act (20 Decs. Comp. Gen. 14 (1940)) or with the Fair Labor Standards Act (20 Decs. Comp. Gen. 24 (1940)), and from rejecting a bid to avoid possible labor difficulties solely on the ground that the low bidder might not employ union labor (3r Decs. CoMp. GeN. 56r (1952)).

${ }^{67}$ See ASPR § I, part 9, 32 C.F.R. 1.900-I.907 (I96I), which broadly deals with the responsibility of prospective contractors. 
the contractor can continue or, in some cases, even begin, performance. If not, the contract can be terminated and the work transferred to another contractor. ${ }^{68}$ Just as it would be irresponsible to award a contract to a contractor who could not perform, so is it improper to leave a contract once awarded in the hands of a contractor who will not perform. If the contractor is able to continue performing despite the strike, or if after a period of nonproduction he resumes performance, the problem next becomes one of whether to grant an extension of time by reason of excusable delay or penalize the contractor for any, failure to meet the established schedule. ${ }^{69}$ The resolution of this question involves determination of whether or not the contractor could have foreseen the strike and whether or not he took all legal steps within his power to end it. ${ }^{70}$ Foreseeability is a particularly important issue when a contractor is delayed by a strike against some other firm. In any event, these determinations are made on a detached basis of reasonable business prudence. Compliance with the Taft-Hartley Act is not separately viewed in this process. Resolution of this ordinarily much contested question could not possibly be achieved by the National Labor Relations Board-the agency to whose expertise the area is committed-in time to serve as a basis of the contracting decision. A patent violation manifestly causing a strike of course would be inconsistent with an objective standard of reasonable business prudence. But these matters rarely loom so clear and the administrative impossibility of awaiting an authoritative decision effectively means that the Taft-Hartley Act, like the Wagner Act and the War Department, is not enforced by the Department of Defense.

The third basic problem when a contractor undergoes a strike arises with cost-type contracts. Surrounded with difficulties of definition, that question, of course, is whether and to what extent costs incurred during a strike will be reimbursed. ${ }^{71}$ Strike costs, it is agreed, should not be awarded. But what is a strike cost? Advertising in the local newspapers to raise public sympathy for management's position and criticism for labor's is, to be sure. So are the range of costs that a company might incur to "beat" a strike. What of the higher overhead unit cost that is the inevitable result of a decreased work force and decreased production? Plainly a company cannot be asked to move to a facility where the rent is lower while its pro-

\footnotetext{
${ }^{08}$ Termination may be either because of default on the part of the contractor or for the convenience of the government depending upon the surrounding facts. If it is for default, the contractor is liable for additional costs incurred in obtaining a replacement. If it is for convenience, the Defense Department must make the contractor whole. ASPR $\S 8,32$ C.F.R. $\$ 8$ (rg6r). The question of whether the termination should be for default or convenience is similar to the question involved in determining excusable delay discussed in the succeeding text.

${ }^{00}$ The contract may contain provisions for liquidated damages for delays, other than those which arise out of unforeseeable causes beyond the control and without the fault or negligence of the contractor. E.g., ASPR 8-709, 32 C.F.R. $\$ 8.709$ ( $(963)$. In addition, the question of default by reason of not meeting the schedule may arise.

${ }_{70}$ ASPR I2-I01.2, 32 C.F.R. § I2.IOI-2 (x963).

${ }^{71} \mathrm{~A}$ similar question may arise in redetermination of fixed price contracts (ASPR 3-404.5-3-404.7, 32 C.F.R. $\$ 3.404-5-3.404 .7$ ( 1963 )) in which provision is made for limited adjustment of the contract price during or after performance. The cost principles applied to cost type contracts are used in evaluating such adjustment (ASPR 15-106, 32 C.F.R. $\$ 15.106$ (I96I)).
} 
duction is diminished by a strike. Between these extremes lies a very large area of costs that are difficult to define. ${ }^{72}$ The process of definition, just as the determination of excusable delay, turns on an objective standard of reasonable business prudence. ${ }^{73}$

This determination, like cost allowability of labor standards and practices, inheres in the contracting authority. So do the issues of excusable delay and capacity to perform. Responsibility for contracting carries with it the necessity to resolve these questions. They are constituent parts of the contracting function.

Beyond this, the interest in obtaining production is subserved by maintaining the closest relationships with the civilian agencies, constantly evaluating the defense impact of any labor dispute, and generally insuring that important disputes receive necessary attention. Occasionally, in particularly critical and rare cases, the Department will effect the removal of needed products from a struck plant. ${ }^{74}$ But the resolution of labor disputes to assure continued production is left to the civilian agencies. The effectiveness of their response makes the basic philosophy consistent with the defense mission.

\section{III}

\section{LABor SUPply}

Essential work cannot be accomplished without workers. Labor is indispensable to production. The availability of sufficient workers-the extent of labor supplycan accordingly be a most serious matter for the Department of Defense. Like labor standards and labor disputes, labor supply may trigger the critical interest in production.

The labor supply problems felt by the National Harness and Saddlery Commission in World War I were greatly magnified during World War II. Labor supply became an issue affecting all industries, pervading the economy.

One industry after another requested the release of military personnel to perform civilian services that were otherwise unavailable. Men were released to work in mines producing nonferrous metals, particularly copper, to work in the aircraft industry, the tire industry, and the forge and foundry industry-all by transfer from active duty to the Enlisted Reserve Corps. Temporary releases of men were effected for food canning, farm equipment repair, and-repeatedly-for agriculture. Former seamen were allowed to apply for discharge to return to the merchant marine. Ninety day furloughs were granted for personnel to work in cotton duck and heavy ammunition and to augment the manpower already made available by release for tires and forge

\footnotetext{
73 The problem is complicated further by the existence of a variety of contract types. In a firm, fixedprice contract, the contractor must absorb all costs. In a cost reimbursement contract, the government must bear all reasonable costs. Between these two are incentive contracts which place an outer limit on the costs contractors may be reimbursed. See ASPR $\$ 3$, part 4, 32 C.F.R. $\$ \S 3.400-3.406-3$ (I96r), for the various types of contracts and their implications.

${ }^{73}$ ASPR I5-20I.3, 32 C.F.R. \$ I5.20I-3 (r96I).

7 Department of Defense Directive No. Ir35.I, Removal of Items from Facilitics Affected by a Work Stoppage, March 22, I951.
} 
and foundry. With the exception of forge and foundry, these industrial furloughs were later extended an additional thirty days. Both release and furlough were utilized to provide workers for the railroads. Although the number of military personnel thus made available to industry was never very large, the criticality of the labor supply problem is highlighted by the fact that they were released. ${ }^{75}$

Discrimination against Negroes aggravated the problems of labor supply, but as the war progressed, their employment opportunities in war industry were dramatically increased. Bolstered by an executive order forbidding discrimination by reason of race, creed, color or national origin, and requiring contract clauses to that effect, Negro employment in war industry more than doubled from $x 942$ to $1945 .^{76}$ As discrimination was diminished, the supply of workers was, of course, enhanced. Quite apart from the compelling moral considerations, discrimination was-as it must be-a senseless waste of our vital manpower resources.

Another and even larger source of labor supply was women. Vigorous efforts were made to bring women out of the home and into war industry. Interestingly enough, these recruitment efforts for industry had their moments of conflict with those for the Women's Army Corps.

Workers from nearby countries were also utilized to ease the labor shortage, mostly in agriculture, but also in industry. From Mexico, the Bahamas, Jamaica and the British West Indies, labor emigrated to supplement the United States manpower resources.

Prisoners of war were put to work, within the bounds of the Geneva Convention. ${ }^{77}$ Agriculture was the most extensive, though not exclusive, area of their use.

Whatever industries the various sources of reinforcement to our industrial manpower serviced, they provided a mobile reserve. As such, they allowed work to be done or crops to be harvested when the need arose. And if they did not work in war industry, they satisfied labor demands that otherwise would have competed with it.

As labor supply became a critical issue, a special civilian agency-the War Manpower Commission-was created by the President. ${ }^{78}$ Addressing itself to the problems of allocating the available manpower, the Commission broadly regulated the field, seeking to alleviate the labor shortages that continually developed and magnified. Its efforts ranged from the imposition of manpower ceilings to free workers from plants where they could be spared to "freeze" orders precluding the transfer of workers from one job to another without a certificate of availability issued by the United States Employment Service. ${ }^{79}$

\footnotetext{
${ }^{75}$ See generally Fatrchild \& Grossman, op. cit. supre note 26 , ch. 8.

${ }^{70}$ Exec. Order No. 8802, 6 Fed. Reg. 3201 (194I).

${ }^{77}$ Under the Convention only privates could be required to work. Moreover, prisoners of war could not be used to perform work which was unhealthful, dangerous or directly related to war operations. Geneva Convention Relating to the Treatment of Prisoners of War, of July 27, r929, Ix 8 L.N.T.S. 343 (1932).

${ }_{78}$ Exec. Order No. 9139, 7 Fed. Reg. 29 r9 (r942).

${ }^{70}$ See Seidman, op. cit. supra note 52, c. 9 .
} 
The War Department also took direct action. From the beginning, efforts were made to locate new facilities in areas in which labor would be available. With the build-up necessitated by the war in Europe and ultimately the World War, plants and airfields had to be constructed. Powder plants, small arms plants, aircraft factoriesa wide range of additional capacity was needed. Prior to the attack on Pearl Harbor, efforts to locate with a view to labor supply met with some success. Following the attack, the rush to begin new construction precluded labor supply from receiving much consideration. But by the summer of 1943 , when labor shortages were being felt, labor supply was firmly established as a major factor in the decision on locating new or expanded facilities. ${ }^{80}$ By this time also, the conflicting restrictions inherent in a pattern of production had similarly developed. Technical skills were discretely located. Contractors had demonstrated their capacity to perform. Questions of locating expanded facilities were easily as intimately tied up with these considerations as with labor supply. Technical skills and proven capacity to perform, moreover, were more immediately visible to contracting officers whose first attention had to be addressed to meeting requirements. Even with available labor, an unproven contractor away from technical skills might have experienced difficulty in performing. In any event, by the time labor supply became an established factor in the location of facilities, the list of areas which did not have a labor problem had so shrunk that the range of alternatives was relatively narrow. As labor supply became an increasingly pressing problem, the capability of the War Department to respond through location of facilities was thus proportionately diminished.

Perhaps the most intensive efforts made by the War Department to resolve problems of labor supply were the special project teams. In early 1943, a critical aircraft manufacturer notified the President that it could not meet its production schedule by summer unless its labor force was increased. By summer, the company was behind schedule. This loss of critical production gave birth to the first special project team, consisting of two men who were dispatched to the company's plant. The team made every effort to attract new workers and to reduce turnover, which had been extreme. It obtained an order of the War Labor Board increasing the company's wage rates which were not competitive. It worked to improve housing in the area and public transportation to and from work. It arranged for the company to pay the child care fees of its employees and for Army reimbursement of this cost. It brought about fundamental changes in the relations between the company and its employees which it found "extremely bad." A1 the team's urging, the company assigned its representative on the grievance board to other work, employed a labor relations executive with authority to establish labor policies, and discontinued a practice that had been a great source of employee resentment. The union was urged to set aside old antagonisms and concentrate on the importance of aircraft production. Previously characteristic inflammatory attacks on the company

\footnotetext{
${ }^{80}$ Fairchild \& Grossman, op. cit. stspra note 26 , at 105.

${ }^{81}$ Id. at 137 .
} 
disappeared from the union newspaper and were replaced by appeals for increased production. The team spoke to community leaders and public newspapers to bring about a more favorable view of the company. Special morale programs were planned for the community as well as the plant.

These actions of the initial team were repeated with great similarity by a total of sixteen others. Of the seventeen special project teams, two, including the first, were designed for a single company, four were concerned with a single area, and eleven dealt with the problems of an entire industry. As their scope ranged, so did their size-from one to forty-five.

Currently, the Department of Defense is much involved in the field of nondiscrimination. The President's Committee on Equal Employment Opportunity functions within a charter greatly expanded beyond the original executive order of World War II. ${ }^{82}$ Constituting as it does the major source of government contracts, the Department of Defense is very active in working with the Committee to the end of insuring equal opportunity for employees and prospective employees of its contractors. In addition, the President's Commission on the Status of Women has recommended that nondiscrimination by reason of sex be advanced through government contracts. ${ }^{83}$ The work of this Commission is being continued and intensified by a new Interdepartmental Committee, on which the Secretary of Defense serves, and a Citizens' Advisory Council. ${ }^{84}$ The Committee and the Council are concerned, as is the Committee on Equal Employment Opportunity, with employment opportunities within and without government. Their interest ranges more broadly, however, over the host of considerations involved in the status of women. ${ }^{85}$

Currently, also, the nation is experiencing an unemployment problem. National attention is importantly focused on finding work.

By the same token, community attention may be focused on the viability of current defense work. Where defense contracts are the main business of local industry, or a military installation is a major local employer, workers who look to defense for job security and companies which do likewise for profits are joined by communities concerned with their general economic health. Cancellation of contracts or inactivation of installations may raise serious community problems. Aware of this potential result of decisions which must be based on considerations of how best to perform the defense mission, the Department of Defense has established an Office of Economic Adjustment, charged with responsibility to work with communities to ease the impact, to help the communities in the development and execution of programs to compensate for the loss of defense work. ${ }^{86}$

${ }^{82}$ See note I6 supra.

${ }^{83}$ Established by Exec. Order No. I0980, on Dec. I4, 1961, 26 Fed. Reg. I2059 (196r), the Commission filed its report to the President on Oct. $\mathrm{x}, \mathrm{x} 963$.

${ }^{84}$ Exec. Order No. IIO30, 29 Fed. Reg. 5847 (I962).

${ }^{86}$ Discrimination on the basis of age has similarly been proscribed. A presidential memorandum of March 14, 1963, asserts the policy against age discrimination in federal employment and Executive Order No. II 14I, Feb. I2, 1964, extends it to the employment of government contractors.

${ }^{80}$ Department of Defense Directive No. 5410.12, Policies and Procedures for Minimizing Economic Impact on Communities Resulting from Adjustments in Defense Programs, Oct. 20, I96r. 
The Department of Defense also remains concerned, as was the War Department in World War II, with the placement of contracts in areas with substantial unemployment. During World War II, efforts were made to place contracts, like facilities, with a view to labor supply. While these efforts were extensive, and resulted in considerable success, the ultimate factor in contract awards, again like facilities, was production. Contracts had to be awarded to firms that would deliver the essential production. Today, Defense Manpower Policy No. 4 serves to "encourage the placement of contracts and facilities in areas of persistent or substantial labor surplus," but its efficacy is restricted by an express prohibition against payment of a price differential. ${ }^{87}$ And the paramount need to obtain the product-enhanced by the overwhelming complexity of much of the current military procurementunderstandably provides a further restriction. With skill and capacity so exactly required, little room is left for locational considerations in seeking production of an intricate weapons system, for example. Performance of the contract, let in furtherance of the mission, measures the defense response to labor supply as well as labor disputes or labor standards.

\section{Conclusion}

Within a basic philosophy of leaving labor policy to the civilian agencies, the defense response to particular labor problems has in the course of time been active and direct. From the complete control over wages and hours of the National Harness and Saddlery Adjustment Commission, to the organization of the Loyal Legion of Loggers and Lumbermen with the promulgation of a charter of working conditions, to the special project teams which plunged into industrial practices and community attitudes, Defense has vigorously participated in a field it philosophically -with equal vigor-eschews.

National urgency may vary from hot war to cold war to peace; urgency for the Department of Defense is a function of the need for the product and the efficacy of the civilian response to the particular labor problem that threatens production. As problem areas are diminished by legislation establishing a framework for resolution, the range of potential Defense action continually narrows. As the civilian agencies, established and special, effectively perform within the framework Congress provides,

${ }^{87} 32$ A C.F.R. App. at 35 (1963). The original Defense Manpower Policy No. 4 allowed payment of a price differential. I7 Fed. Reg. II95 (1952). Riders attached to Defense appropriations overruled this aspect of the policy, and it was accordingly changed to include the express prohibition. The basis of Defense Manpower Policy No. 4 has also undergone some change. Originally, it sounded mostly in mobilization: "The conversion from civilian to military production, unless carefully coordinated, would result in dislocations causing serious waste of manpower and facilitics in many arcas, and thercby reducing our defense potential. The overriding need is to obtain on schedule the goods and services required for defense. In achieving this goal, every effort must be made to hold to a minimum any waste of manpower which may result from materials shortages and conversion to defense production." It now has been broadened to look beyond mobilization to "economic balance" and "employment stability": "When large numbers of workers move to already tight areas, heavy burdens are placed on community facilities-schools, hospitals, housing, transportation, utilities, and so forth. On the other hand, when unemployment develops in certain areas, unemployment compensation costs increase and plants, tools, and workers' skills remain idle and unable to contribute to our defense programs." 
the need for Defense action similarly dwindles. Bordered by a decreased range and need, the capacity for Defense action also lessens. The steadily magnifying complexity of military procurement reduces the number of potential contractors able to meet the exacting requirements and, concomitantly, flexibility in selection among competitors.

Beyond such matters as cost allowability and excusable delay which must attend the contracting process, the defense response has always been dictated by its mission. The contract is let in furtherance of that mission. The criticality of performance is measured by it. When the defense of the nation is involved, when national security demands, Defense responds to problems of labor policy definitively.

The basic philosophy of leaving labor policy to the civilian agencies stands. Its desirability is buttressed by their effectiveness. Fulfillment of the Defense mission, however, is the ultimate commitment. 